Natural Hazards and Earth System Sciences, 5, 717-725, 2005

SRef-ID: 1684-9981/nhess/2005-5-717

European Geosciences Union

(C) 2005 Author(s). This work is licensed

under a Creative Commons License.

\title{
1881 and 1949 earthquakes at the Chios-Cesme Strait (Aegean Sea) and their relation to tsunamis
}

\author{
Y. Altinok ${ }^{1}$, B. Alpar ${ }^{2}$, N. Özer ${ }^{1}$, and C. Gazioglu ${ }^{2}$ \\ ${ }^{1}$ Istanbul University, Engineering Faculty, Department of Geophysics, 34850 Avcilar, Istanbul, Turkey \\ ${ }^{2}$ Istanbul University, Institute of Marine Sciences and Management, 34116 Vefa, Istanbul, Turkey \\ Received: 24 March 2005 - Revised: 2 August 2005 - Accepted: 8 September 2005 - Published: 23 September 2005 \\ Part of Special Issue "Tsunami hazard from slope instability"
}

\begin{abstract}
The most earthquake-prone areas in the eastern central Aegean Sea are the Izmir Bay, the Karaburun peninsula and the island of Chios. The level of seismic activity and tsunami potential are influenced by the presence of normal faults around the region. There have been about 20 moderate-size earthquakes from 496 BC to 1949 AD. Among these earthquakes, the ones on the dates 20 March 1389, 13 November 1856, 19/22 January 1866, 3 April 1881 and 23 July 1949 produced tsunamis. The Chios-Cesme earthquake (1881, Mw 6.5) took place in the South of the Cesme strait while the Chios-Karaburun earthquake (1949, Mw 6.7) occurred in the North. The tsunamis caused by the earthquakes affected the coasts of Chios Island and Cesme. These waves are thought to be associated with the earthquakes and co-seismic underwater failures possibly occurred along the coasts of the Chios Island and Karaburun Peninsula or on the complex subaqueous morphology between these lands. Some sea waves or oscillations observed following the aftershocks are believed to be related to other natural phenomena; e.g. the seiches occurred mainly in open-narrow bays as triggered by the earthquakes.
\end{abstract}

\section{Introduction}

The coastal areas of the Aegean Sea have experienced tsunamis many times in history. The generation mechanisms and their characteristics have not been well described. According to the historical information, or the distribution of fault zones, volcanoes, and other probable tsunamigenic sea bottom formations, there are numerous source areas which may be considered responsible for these tsunamis. Between the North Anatolian fault zone in the North, and the Hellenic Arc in the South, one of the important source areas of tsunamis in the Aegean region is the Chios (Sakiz)Karaburun region (central Aegean Sea) (Fig. 1). This re-

Correspondence to: Y. Altinok

(yaltinok@istanbul.edu.tr) gion is situated at the first-degree hazard zone in the Official Earthquake Hazard Regionalization map of Turkey (1996) and is currently accelerating its seismic activity. Papazachos et al. (2004) demonstrated the possibility of a very severe event in the near future with magnitudes reaching up to $M$ 6.5-6.7. Using a combination of instrumental, historical, and geodetic data, Koravos et al. (2003) proposed the maximum earthquake magnitude at $7.2 \pm 0.1$ for Karaburun Peninsula and at $7.6 \pm 0.2$ for the western part of the island of Chios.

Being famous for its historical heritage, this region is located in the western part of the Gediz and Menderes graben systems and contains several morphologically prominent active normal faults with an approximate East-West strike. Moreover, the NE-SW and NW-SE trending faults, with their changing kinematic characteristics from north to south, take major roles on the tectonic regime of the region (Yilmaz, 1997).

Throughout history, earthquakes have been the most damaging natural disasters that have affected the area. There have been at least 15 disastrous earthquakes with magnitudes greater than 6.0 reported in the literature. In the last two centuries, the event of Chios-Cesme on 3 April 1881 and the 23 July 1949 Chios-Karaburun event caused much damage. They caused many landslides along the coastal area of Chios Island and the Karaburun Peninsula. Landsliding is commonly triggered by any earthquake with a magnitude greater than 5; e.g. the 16 December 1977 Izmir earthquake $(\mathrm{Mb}=5.3$; Eyidogan et al., 1991) triggered a landslide that caused the collapse of 750 houses (Wormsworth, 2003). The Chios-Cesme on 3 April 1881 and the 23 July 1949 ChiosKaraburun earthquakes caused some sea waves which affected the coasts of Chios Island and Cesme town, an important tourism resort in the Karaburun Peninsula. The informative sources for these tsunamis, however, are rather scarce and most of the documents are in ancient (Greek and Ottoman) languages.

The scope of this study is to gather all possible informative data, to control or strengthen available information with new evidences or facts gathered from several sources. Therefore 


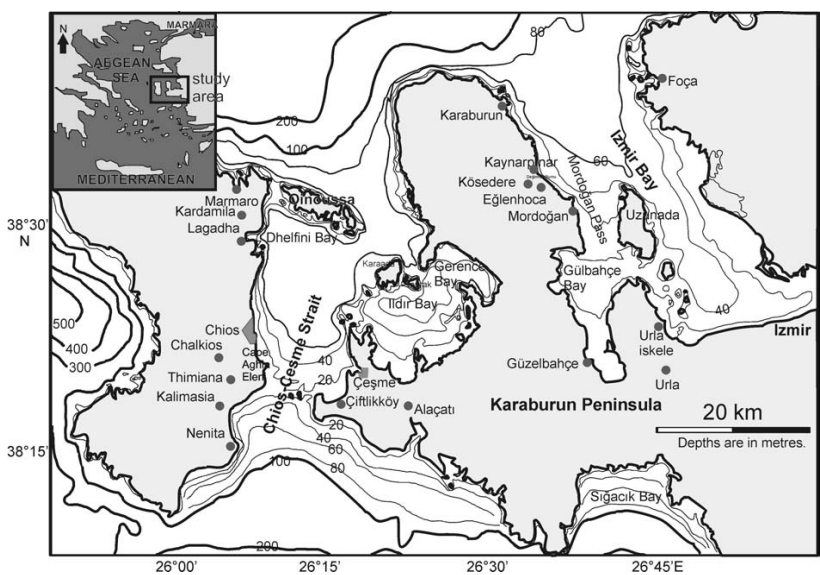

Fig. 1. Map of the study region (see inset for location) showing bathymetry and place names mentioned in text. Bathymetric data were obtained by digitising 20-m contours of 1:300 000 scale British Admiralty and 1:75000 scale Turkish governmental charts.

we have analysed many historical records in the Ottoman journals, which were recently opened to the public, as well as international, modern Turkish and Ottoman journals, press reports and other relevant studies. Written documents helped us update available isoseismal maps to get an understanding of the origin of the events. Together with bathymetric data, geological settings, the (historical and instrumental) seismic activity of the region and satellite images, these maps were used to interpret the general features of these two typical events.

\section{Geological frame}

The Aegean Region is one of the most rapidly moving and seismically active parts of the Alphine-Himalayan Mountain Belt. The Aegean Plate is bound in the North by the western extension of the North Anatolian Fault. The southern boundary of the Aegean plate passes through the Hellenic Trench and the Pliny/Strabo complex, in the south of Crete and Rhodes (McKenzie, 1978). The main deformation in the region arises from the N-S extension of the Aegean plate which is due to subduction of the oceanic lithosphere under the Aegean plate in the Hellenic Arc and the westward motion of the Anatolian plate. On the basis of GPS measurements, global kinematic models, the analysis of oceanic spreading, fault systems, and earthquake slip vectors; the relative plate motions along the North Anatolian fault zone $(25 \mathrm{~mm} / \mathrm{a}$ westward) and across the South Aegean Trench (40-50 mm/a southwestward) cause diffuse deformation (extension) in the Aegean plate, behind the South Aegean Arc (Dewey and Sengör, 1979; Barka and Reilinger, 1997). The anomalous low elevated extensional Aegean region allows Anatolia to move with systematically increasing velocity to the W-SW which leads the westward opening of Izmir Bay, bound by normal faults. Parallel and E-W striking major

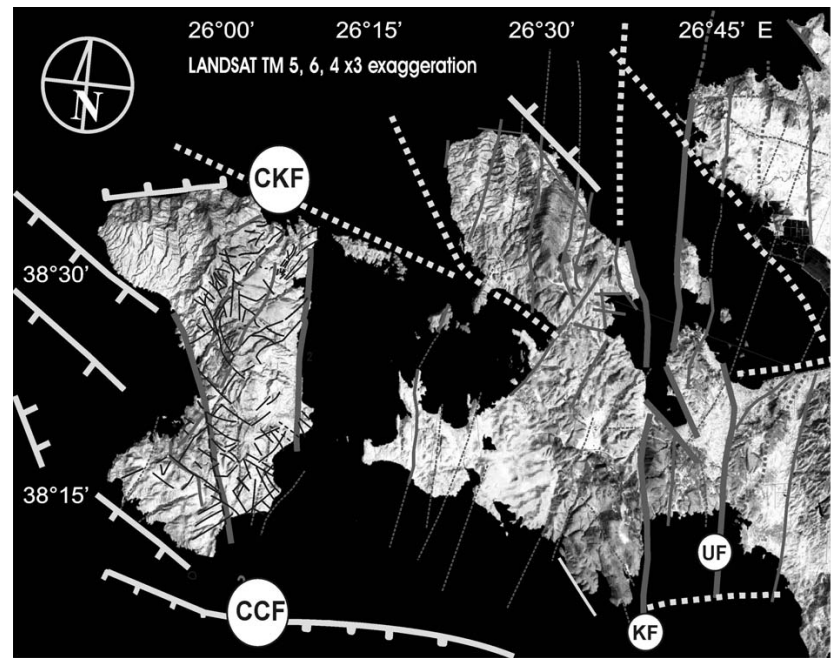

Fig. 2. The principal (KF: Karaburun, UF: Urla) and other minor faults observed from both satellite images and site investigations extend NS in general. On the basis of neotectonic studies and seismic activity information, EW oriented subaqueous faults (CCF: ChiosCesme fault, CKF: Chios-Karaburun fault) should also be considered for possible source locations of Chios-Cesme (3 April 1881) and Chios-Karaburun (23 July 1949) earthquakes.

troughs on land (Izmir and Menderes grabens) continue west into the Aegean basin (Mascle and Martin, 1990).

The Chios-Karaburun region, which is one of the most seismically active parts of the Aegean Region, is situated in western Turkey in the Izmir-Ankara Zone, to the South of the Sakarya Domain and to the North of the Menderes Massif. The region presents a complex geographical profile and is surrounded by an uneven sea and bays (Fig. 2). The north-south oriented Bozdag range (with its $1212 \mathrm{~m}$ high Akdag peak) forms the backbone of the Karaburun Peninsula $\left(415 \mathrm{~km}^{2}\right)$. Beyond localized plane areas (Mordogan, Yeniliman, Badembükü and Denizgiren), the mountains or steep slopes fall directly into the sea in many places. The coastal line along the Izmir Bay and the northern and eastern shores of the Karaburun Peninsula are marked by many bays and coves. The Peninsula is also surrounded by a number of uninhabited islands. To the West, there are a large number of Greek islands scattered in the Aegean Sea. Chios is one island in the Northeast Aegean archipelago.

The Chios-Karaburun region shows a very complex and rapidly changing tectonic pattern due to the relative motions of surrounding tectonic plates. In spite of important Neogene tectonic complications, a complete stratigraphic sequence of pre-Neogene rocks exists in the region (Besenecker et al., 1971; Brinkmann et al., 1972; Erdogan et al., 1990; Papanikolaou and Sideris, 1992; Kozur, 1998; Robertson and Pickett, 2000). A thick Mesozoic platform resting in discordance on a Paleozoic mélange is linked to the important Neogene extension which still affects the region (Isintek et al., 2000; Rosselet and Stampfli, 2002). The principal and some secondary faults were superimposed on the satellite image 


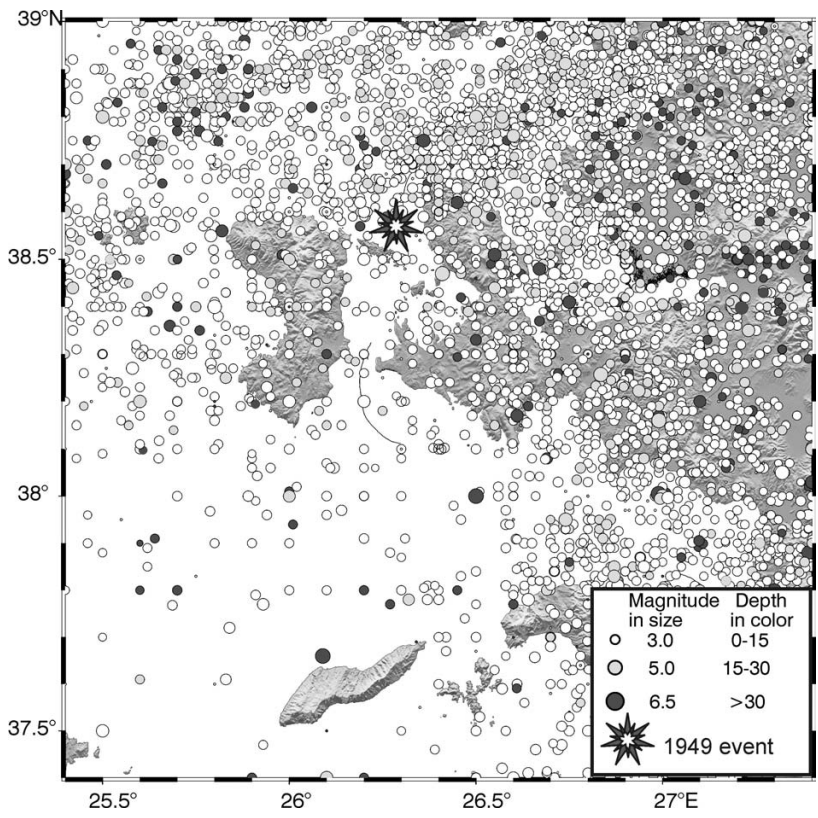

Fig. 3. Instrumental earthquakes occurred between 1900 and 2005 . Data is provided from the web page of Kandilli Observatory. Circle size represents the magnitude of the earthquake, and ranges from 0 to 6.8. The figure was drawn using the GMT software (Wessel and Smith, 1998).

map (Fig. 2), interpreting satellite images, geological setting and available marine seismic reflection data sets. The ChiosCesme fault (CCF) was defined by Westaway (1994).

\section{Earthquakes in the region}

Throughout history, earthquakes have been the most damaging natural disasters that have affected the study area. Historical events (before 1900) are usually difficult to draw on a map because their estimated epicentre locations usually coincide partially or wholly; therefore they are listed in Table 1. The events occurred between 1900 and 2005 have occurred mainly in the northern part of the Chios Island and Karaburun Peninsula (Fig. 3), indicating the Aegean extension of graben systems in the western part of Anatolia.

Some earthquakes that created tsunamis are the ones on 20 March 1389, 13 November 1856, 19 January 1866, 3 April 1881 and 23 July 1949. On 20 March 1389, the sea waves in the Chios-Cesme Strait reached up to the middle of the marketplace at the eastern part of the town of Chios and forced people to leave (Papazachos and Papazachou, 1997). Swelling of the wave was noted when it passed through the Chios-Cesme Strait (Soleviev et al., 2000).

On 13 November 1856, some large waves hit the land and caused the disappearance of some people in Chios (Papazachos and Papazachou, 1997; Soleviev et al., 2000). Based on our documental searches, the date of this event may be 11/12 October 1856 (02:45 local time) with no tsunami information (Journal de Constantinople, 19 October 1856; Ceride-i

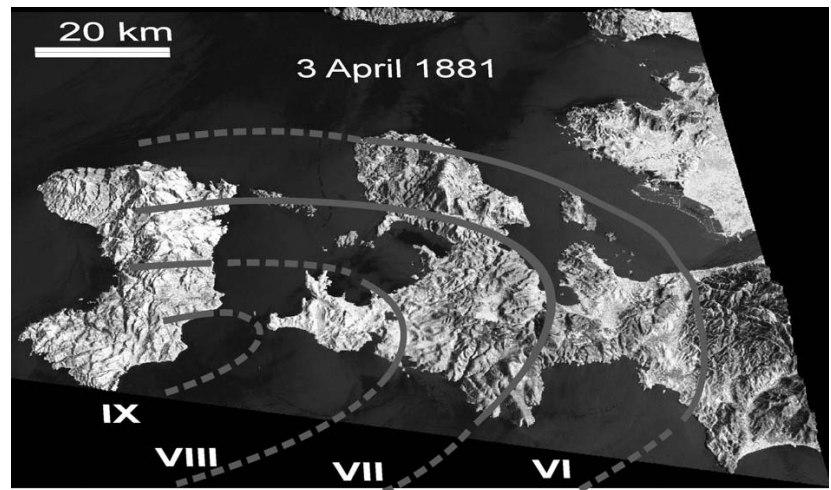

Fig. 4. Isoseismal map of Chios-Cesme Earthquake, 3 April 1881, realized in the present study on the basis of Henriet (1883) and the data listed in Table 2.

Havadis, 28/29 October 1856). If they are not a same earthquake, then the 11/12 October 1856 event should be a new one (Table 1).

On 19 January 1866, intensive boiling of the sea water was observed in the Chios-Cesme Strait (Soleviev et al., 2000).

\subsection{The Chios-Cesme earthquake (3 April 1881)}

38.3N; 26.2E; Mw=6.5; Io=IX (MSK) (Henriet, 1883; Papazachos and Papazachou, 1997).

On Sunday 01:40 pm local time, the Chios and Karaburun Peninsula were hit by a very severe earthquake in which over 4000 people lost their lives and more than half the villages were seriously damaged (Table 2). The town of Chios was devastated and has never fully recovered - bearing the deep scars of both man-made and natural catastrophes (Kastaniya, 1983). The epicenter of the earthquake was in the Southeast of the island of Chios (BOA, YEE 78/143). The most affected areas stretch from the Dhelfini Bay (Kolkythyia) of Chios and the Spalmadores islands (i.e. Oinoussa) to the North, a few kilometers near Izmir in the East, and to the islands of Samos and Ikaria in the South. Up to $2.5 \mathrm{~m}$ vertical displacements were observed (Tercüman-i Hakikat, 10 April 1881 ) and up to $75 \%$ of buildings in the island of Chios were damaged (Henriet, 1883). In this study, the isoseismal map of the Chios-Cesme earthquake has been created from the data listed in Table 2 and from Henriet's work (1883). Our isoseismal contours (Fig. 4) are slightly different from those drawn previously by Galanopoulos (1954) and generalized later by Shebalin (1974). Although our epicentral intensity is consistent with that given by Shebalin (1974), our isoseismal contours are more elliptical, contrary to the circular ones given in the abovementioned previous studies.

The town of Chios was devastated and has never fully recovered - bearing the deep scars of both man-made and natural catastrophes. Only about 10000 inhabitants survived the earthquake. The number of casualties was high, mainly due to the narrow streets of Chios ( $2-4 \mathrm{~m}$ in width). Bodies lay piled in the streets in the summer heat while the inhabitants 
Table 1. List of historical earthquakes occurred in the Chios Island and vicinity till 1900. (1) Soysal et al. (1981); (2) Ambraseys and Finkel (1995); (3) Papazachos and Papazachou (1997); (4) Soloviev et al. (2000) and this study; as compiled from Ottoman newspapers named (5) Ceride-i Havadis, (6) Journal de Constantinople, (7) Takvim-i Vekayi.

\begin{tabular}{|c|c|c|c|c|c|c|c|c|}
\hline Date & Hour & Latitude $(\mathrm{N})$ & Longitude (E) & $I_{0}$ & M & Region & Reference & Remarks \\
\hline 496 B.C & & $38.4^{\circ}$ & $26.2^{\circ}$ & VIII & $\mathrm{M}_{W}(6.2)$ & Chios & 3 & \\
\hline 177 A.D & & $38.4^{\circ}$ & $\left(27.1^{\circ}\right)$ & $\mathrm{X}$ & & $\begin{array}{l}\text { Izmir,Milet, } \\
\text { Chios, Samos }\end{array}$ & 1 & \\
\hline $20 / 03 / 1389$ & & $\begin{array}{l}38.4^{\circ}(1,3), \\
38.25(4)\end{array}$ & $\begin{array}{l}26.3^{\circ}(1,3), \\
26.25(4)\end{array}$ & VIII (3), IX (1), X (4) & $\mathrm{M}_{W} 6.7(3), \mathrm{M}_{S} 6.8$ (4) & $\begin{array}{l}\text { Chios (3) } \\
\text { Chios and } \\
\text { Asia Minor } \\
\text { (4), Izmir and } \\
\text { Chios (1) }\end{array}$ & $1,3,4$ & Tsunami \\
\hline 1546 & & $38.2^{\circ}(3)$ & $25.9^{\circ}(3)$ & VII (3) & $\mathrm{M}_{W} 6.3(3)$ & $\begin{array}{l}\text { Chios, Mas- } \\
\text { tichochoria } \\
\text { (Katomeria) }\end{array}$ & 2,3 & \\
\hline 1565 & & & & & & Chios & 2 & \\
\hline $1645-1646$ & & & & & & $\begin{array}{l}\text { Aegean, } \\
\text { Chios }\end{array}$ & 2 & \\
\hline 1684 & & $38.3^{\circ}(3)$ & $26.2^{\circ}(3)$ & VI (3) & $\mathrm{M}_{W}(6.0)(3)$ & Chios & 2,3 & \\
\hline $05 / 03 / 1694$ & 03:00 & & & & & Chios & 2 & \\
\hline $20 / 12 / 1738$ & $\begin{array}{l}\text { Sunday } \\
11: 00 \text { (2), } \\
12: 00(3)\end{array}$ & & & & & Chios & 2,3 & \\
\hline $23 / 12 / 1738$ & $\begin{array}{l}05: 30 \\
\text { at night (2) } \\
22: 00(3)\end{array}$ & $38.5^{\circ}(3)$ & $26.3^{\circ}(3)$ & VI (3) & $\mathrm{M}_{W}(6.0)(3)$ & Chios & 2,3 & \\
\hline $07 / 02 / 1767$ & & & & & & Chios & 2 & \\
\hline $25 / 10 / 1772$ & $\begin{array}{l}\text { at mid- } \\
\text { night }\end{array}$ & & & & & Chios & 2 & \\
\hline 09/1831 & & $\left(38.40^{\circ}\right)$ & $\left(26.0^{\circ}\right)$ & & & Chios & 1 & \\
\hline $28 / 12 / 1843$ & & $\left(38.40^{\circ}\right)$ & $\left(26.0^{\circ}\right)$ & & & Chios & 1 & \\
\hline $11 / 03 / 1846$ & & $38.50^{\circ}$ & $26.50^{\circ}$ & VI & & $\begin{array}{l}\text { Karaburun- } \\
\text { Izmir, Lesvos } \\
\text { and Samos } \\
\text { Islands }\end{array}$ & 1 & \\
\hline $11+12 / 10 / 1856$ & $02: 45$ & & & & & Chios, Izmir & 5,6 & \\
\hline $13 / 11 / 1856$ & & $\begin{array}{l}38.4^{\circ} \quad(3), \\
38.25^{\circ}(4)\end{array}$ & $\begin{array}{l}26.1^{\circ} \\
26.25^{\circ}(4)\end{array}$ & VIII & $\mathrm{M}_{W}(6.3)(3), \mathrm{M}_{S} 6.6(4)$ & Chios & 3,4 & Tsunami \\
\hline 20/09/1859 & & $\left(38.50^{\circ}\right)$ & $\left(26.0^{\circ}\right)$ & (VI) & & Chios & 1 & \\
\hline $16 / 08 / 1863$ & & $\begin{array}{l}38.3^{\circ} \quad(3), \\
38.25^{\circ}(1)\end{array}$ & $26.1^{\circ}(3)$ & VIII $(1,3)$ & $\mathrm{M}_{W}(6.2)(3)$ & Chios & 1,3 & \\
\hline $11 / 11 / 1865$ & & $38.3^{\circ}$ & $26.2^{\circ}$ & VIII & $\mathrm{M}_{W}(6.1)$ & Chios & 3 & \\
\hline $13 / 01 / 1866$ & & $38.25^{\circ}$ & $26.2^{\circ}$ & VII & & $\begin{array}{l}\text { Chios, Gelibolu, } \\
\text { Bursa, Edirne }\end{array}$ & 1 & \\
\hline
\end{tabular}


Table 1. Continued.

\begin{tabular}{|c|c|c|c|c|c|c|c|c|}
\hline Date & Hour & Latitude $(\mathrm{N})$ & Longitude (E) & $I_{0}$ & M & Region & Reference & Remarks \\
\hline $19+22 / 01 / 1866$ & $12.30(4)$ & $38.25^{\circ}(1)$ & $26.2^{\circ}(1)$ & VII $(1,4)$ & $\mathrm{M}_{S} 6.8(4)$ & Chios Strait & 1,4 & Tsunami (4) \\
\hline & & $38.25^{\circ}(4)$ & $26.25^{\circ}(4)$ & & & & & \\
\hline $02 / 02 / 1866$ & & $\begin{array}{l}38.4^{\circ} \quad(3), \\
38.25^{\circ}(1)\end{array}$ & $\begin{array}{l}26.0^{\circ}(3), 26.25 \\
\text { (1) }\end{array}$ & VIII $(1,3)$ & $\mathrm{M}_{W}(6.4)$ & Chios & 1,3 & \\
\hline 08/10/1871 & $11: 10$ & $38.4^{\circ}$ & $26.1^{\circ}$ & VIII & & Chios & 1 & \\
\hline $01 / 11 / 1875$ & & $38.6^{\circ}$ & $26.5^{\circ}$ & VII & & $\begin{array}{l}\text { Karaburun, } \\
\text { Mordogan }\end{array}$ & 1 & \\
\hline 05/11/1875 & 09:45 & $38.6^{\circ}$ & $\left(26.0^{\circ}\right)$ & VI & & $\begin{array}{l}\text { Chios, } \\
\text { Karaburun }\end{array}$ & 1 & \\
\hline 03/04/1881 & $\begin{array}{l}11: 40 \quad(3), \\
11: 30(1)\end{array}$ & $\begin{array}{l}38.3^{\circ}(3), \\
38.25^{\circ}(1), \\
38.2^{\circ}(4)\end{array}$ & $\begin{array}{l}26.2^{\circ}(3) \\
26.1^{\circ}(1,4)\end{array}$ & IX (3), X (1) & $\mathrm{M}_{W} 6.5(3) \mathrm{M}_{S} 6.5$ (4) & $\begin{array}{l}\text { Chios }(3,4), \\
\text { Chios, } \\
\text { Cesme(1) }\end{array}$ & $1,3,4$ & Tsunami \\
\hline 21/03/1882 & & $38.4^{\circ}$ & $26.1^{\circ}$ & VII & & (Chios) & 1 & \\
\hline $15 / 10 / 1883$ & $\begin{array}{l}15: 30 \quad(1, \\
3)\end{array}$ & $38.3^{\circ}(1 ; 3)$ & $\begin{array}{l}26.3^{\circ}(1), \\
26.6^{\circ}(3)\end{array}$ & IX $(1,3)$ & $\mathrm{M}_{W} 6.8(3)$ & $\begin{array}{l}\text { Cesme (3), } \\
\text { Cesme Penin- } \\
\text { sula, Chios } \\
\text { (1) }\end{array}$ & 1,3 & \\
\hline $01 / 11 / 1883$ & & $38.3^{\circ}$ & $26.3^{\circ}$ & VIII & & $\begin{array}{l}\text { Cesme Penin- } \\
\text { sula }\end{array}$ & 1 & \\
\hline 27/11/1886 & 08:05 & $38.25^{\circ}$ & $26.1^{\circ}$ & VII & & $\begin{array}{l}\text { Chios,Cesme, } \\
\text { Izmir }\end{array}$ & 1 & \\
\hline $11 / 12 / 1886$ & & $38.4^{\circ}$ & $26.1^{\circ}$ & VIII & & Chios, Izmir & 1 & \\
\hline $15 / 03 / 1888$ & & $38.4^{\circ}$ & $26.1^{\circ}$ & VI & & Chios & 1 & \\
\hline $05 / 1888$ & & $38.4^{\circ}$ & $26.1^{\circ}$ & VIII & & $\begin{array}{l}\text { Chios, } \\
\text { Cesme, Urla, } \\
\text { Karaburun }\end{array}$ & 1 & \\
\hline 26/05/1890 & & $38.5^{\circ}$ & $25.5^{\circ}$ & VII & $\mathrm{M}_{W}(6.2)(3)$ & $\begin{array}{l}\text { Psara, Chios, } \\
\text { Rhodos(1), } \\
\text { Psara (3) }\end{array}$ & 1,3 & \\
\hline 26/03/1891 & & $38.4^{\circ}$ & $26.1^{\circ}$ & VI & & $\begin{array}{l}\text { Chios and en- } \\
\text { virons islds. }\end{array}$ & 1 & \\
\hline 07/04/1891 & & $38.4^{\circ}$ & $26.1^{\circ}$ & IV & & $\begin{array}{l}\text { Chios and en- } \\
\text { virons }\end{array}$ & 1,7 & \\
\hline 03/11/1891 & $06: 15$ & & & & & Chios, Urla & 7 & \\
\hline 09/11/1891 & 13:00 & & & & & Chios & 7 & \\
\hline 21/11/1891 & $06: 30$ & & & & & Urla, Cesme & 7 & \\
\hline 01/12/1891 & $04: 30$ & & & & & Urla & 7 & \\
\hline $27 / 12 / 1892$ & $18: 30$ & $37.75^{\circ}$ & $27.0^{\circ}$ & VII & & Chios & 1 & \\
\hline
\end{tabular}

were too weak to bury them all. Eventually typhoid pits were dug. Almost all of the churches were destroyed, minarets were toppled (Sannav, 2004). The most affected areas in Chios are thought to be the villages in the south (Nenita, Vouno, Flatsia, Kalamote, Koene, Kallimasia and Didyma), but the damage was especially devastating in Nenita, $20 \mathrm{~km}$ south of the town of Chios (BOA, Y.PRK.PT.1/76; L'Agence Havas, 9 April 1881). In Cesme and Alacati (Alatzata), casualties were low because most of the people were on the sea shore watching the passage of the great passenger ship Aya Evangelistra (Impartial, 7 April 1881).
In Chios, cracks were formed on the soil with other cracks crossing the former perpendicularly. Telephone and telegram lines were cut off. At the Cape Aghia Eleni, $4 \mathrm{~km}$ south of Chios Town, the soil is cut through about $50 \mathrm{~m}$ long in EW direction and soil subsidence occurred (Vogt, 1999). The dome of the monastery Gregorios Photeinos which was given an extensive restoration work and had its external appearance completely altered in 1857 , collapsed in the earthquake of 1881 (Hellenic Ministry of Culture web site, last access 2005) 
Table 2. Statistics of losses during 3 April 1881 event (Impartial, 7 April 1881; L'Agence Havas, 9 April 1881, 14 April 1881; Vakit, 10 April 1881; BOA, Y.PRK.PT.1/76).

\begin{tabular}{lcccc}
\hline Place & Casualties & Injures & Houses destroyed & Houses damaged \\
\hline Chios Town & 500 & 600 & & \\
Thimiana, Kalimasia & 600 & 900 & & \\
Nenita & 1200 & 1500 & & \\
Chios Island (Total) & $\mathbf{3 5 5 0}$ & $\mathbf{7 0 0 0}$ & $\mathbf{2 5 \%}$ & $\mathbf{5 0 \%}$ \\
Cesme & 50 & 150 & $1000 / 2600$ & $1600 / 2600$ \\
Alacati & 26 & 300 & $800 / 1800$ & $1000 / 1800$ \\
Kato Panaya (Ciflikköy) & 25 & 450 & 900 & 500 \\
\hline
\end{tabular}

Table 3. Statistics of losses during 23 July 1949 earthquake (Aksam, 25 July 1949; Son Posta, 25 July 1949; Papazachos and Papazachou, 1997; Soleviev et al., 2000).

\begin{tabular}{lcccc}
\hline Place & Casualties & Injures & Houses destroyed & Houses damaged \\
\hline Kardamila Region & 3 & 50 & $60 \%$ & $33 \%$ \\
Chios Town & - & 20 & $\% 2$ & $8 \%$ \\
\hline Chios Island (Total) & $\mathbf{7}$ & $\mathbf{5 0}$ & $\mathbf{8 9 1}$ & $\mathbf{2 5 2 6}$ \\
Karaburun & 2 & 9 & 407 & 250 \\
Cesme Region & - & - & $70 \%$ & 90 \\
\hline Karaburun Region (Total) & - & - & $\mathbf{1 6 8 1}$ & $\mathbf{3 8}$ \\
\hline
\end{tabular}

No new water springs were formed and the springs already present were left intact. One exception is close to Kastro, close to the south end of the castle, where sand boiling occurred due to liquefaction. Underground water broke through the solid surface much like a bubble in boiling water which is reported to have been as high as $1 \mathrm{~m}$, and created fissures in the coast. A herd perished under a landslide and rockfalls in Chalkios (Papazachos and Papazachou, 1997; Vogt, 1999). Coupled lateral and torsional movements produced non-uniform displacement and caused subsidence (Impartial, 7 April 1881).

Near Kastro, the sea bottom sunk $80 \mathrm{~cm}$ (Papazachos and Papazachou, 1997). As opposed to this finding, the sea floor between the Chios island and the mainland (i.e. Karaburun Peninsula) rose; the 40 fathoms $(73 \mathrm{~m})$ depth of the strait were measured to be 15 fathoms $(27 \mathrm{~m})$ after the earthquake (L'Agence Havas, 13 April 1881; La Turquie, 14 April 1881; Vakit 15 April 1881). This is an extraordinary change and can hardly be explained by dip-slip faulting associated to a medium earthquake ( $\mathrm{Mw}=6.5)$. This information may force one to think about possible landslides or underwater failures having occurred somewhere between the island of Chios and the mainland.

A few minutes after the main shock, a strong aftershock occurred destroying the buildings that had not taken any damage during the main shock (Henriet, 1883). Other aftershocks occurred approximately every $15 \mathrm{~min}$. In addition, the strong aftershock that occurred on 4 April 1881 caused the island mass to sink $1 \mathrm{~m}$ (L'Agence Havas, 14 April 1881; Vakit, 15 April 1881). On 5 April at 03:10 a.m., a strong vertically effective earthquake demolished some city walls. The sea became wavy right away and a mass of smoke was seen rising from sea surface (Impartial, 5 April 1881).

Some spots of fresh sand were found in the wall of the garden in Chios (Papazachos and Papazachou, 1997). This may imply that a sea wave (tsunami) occurred, possibly after the main shock. Meanwhile, it is known that the aftershocks created waves on the sea surface (Benndorf, 1884). Lots of empirical formulations (e.g. Tadepalli and Synolakis, 1994; Watts, 1998; Walder et al., 2003) can forecast the runup of tsunami waves on inclined slopes. Using such formulations, when the wave runup is known, it is possible to get some information about the water waves. Since the locality of this place is not defined, however, it is almost impossible to get some information about the tsunami parameters.

\subsection{The Chios-Karaburun earthquake (23 July 1949)}

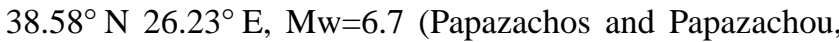
1997); Ms=6.6 (Ambraseys, 1988).

This earthquake occurred on Saturday 18:03:30 local time and was felt in Söke, Odemis, Edremit, Canakkale, Alasehir, Tire, Bandirma and Ayvalik (Pinar, 1950). The epicenter of the earthquake was in the center of a triangle between Cesme, Chios and Karaburun. Ambraseys (1988) locates the epicenter as being on the island of Oinoussa (Koyunada). The most affected area was Karaburun: 407 houses were damaged, 2 


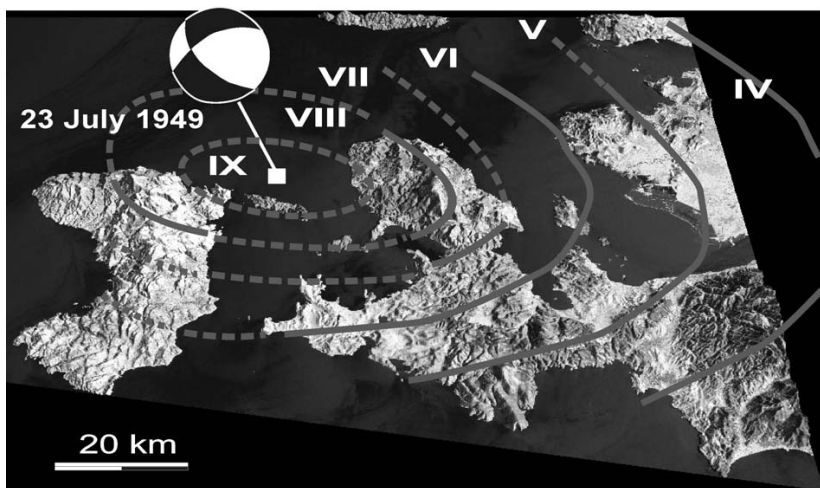

Fig. 5. Isoseismal map of Chios-Karaburun Earthquake, 23 July 1949 as modified from Erkman (1949). Focal mechanism solution indicates normal faulting (Eyidogan, 1988).

people were killed, and 9 were injured (Table 3). In Cesme $70-80$ houses were damaged. In the island of Chios, a total of 50 people were injured. The north-eastern part of the island of Chios was one of the most affected areas (Fig. 5).

The area of Kardamila encompasses the largest part of Northeast Chios, bordering a mountainous mass in the west. The rocks are sedimentary, mainly slate, limestone and dolomite. Towards the North and the East, there are a great number of bays and the ports of Marmaro and Parpanta. In Kardamila, $60 \%$ of the houses were destroyed and in Marmaro, 50 buildings collapsed. A big fissure $200 \mathrm{~m}$ long appeared near Marmaro along the artificial shore and small fissures appeared in the streets of the village. Numerous stone screes and soil avalanches occurred precisely on the northern slopes of the mountains of Pelinaion (Soleviev et al., 2000). In Chios, the port sank $35 \mathrm{~cm}$ into the sea (Vatan, 25 July 1949). Houses on the sea shore were destroyed. All telecommunications between Chios and Cesme were cut off, not because of severed cables, but due to collapsed operator buildings (Aksam 24 July 1949). In Lagadha town, back of the large and deep ( $>50 \mathrm{~m}$ ) Dhelfini Bay, rockfalls occurred (Aksam, 25 July 1949). In Karaburun too, boulders were torn out of mountains. Rock blocks in Degirmenburnu, Kösedere (Akburun Hill), Yartepe and Kaynarpinar along the NE region of the Karaburun Peninsula rolled into the sea (Erkman, 1949; Vatan, 25 July 1949).

Some unusual events occurred during the earthquake. In Cesme, $5 \mathrm{~km}$ away in the direction of Cape Yildiz, grey coloured water gushed out of the sea, the height of the jet being up to $15 \mathrm{~m}$ (Aksam, 25 July 1949; Hürriyet, 25 July 1949; Son Posta, 25 July 1949; Vatan 25 July 1949). The flow of the water network increased for the next 3-4h. The sea between Chios and Cesme turned red in colour and became turbid for a few hours. Hot natural springs disappeared in Karaburun, re-emerging later in different locations. The sea attacked the coasts of Cesme town, leaving many dead fish behind after it subsided. Fishermen are reported to have described flames spurting out of the sea surface (Cumhuriyet, 24 July 1949). In Chios the runup was about $2 \mathrm{~m}$ high and the

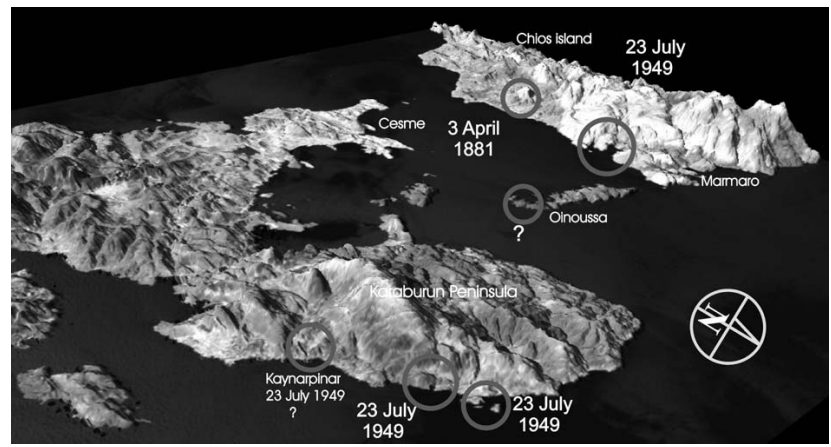

Fig. 6. Natural view image Drape-LANDSAT (7/5/36) of the region supports known landslides that occurred usually at the NE parts of the Karaburun Peninsula (e.g. Akburun Hill in 1949), Chios (Chalkios in 1881 and Lagadha in 1949). The landslides proposed in the Oinoussa islands and Kaynarpinar are based on speculations arising from the study of these images.

sea waves flooded the beach (Papazachos and Papazachou, 1997).

The earthquake was preceded by a few weaker shocks on 21 and 22 May. After the earthquake, a total of 44 aftershocks occurred up to 11 September, including the very strong shocks of 28-30 July and 24 August. The 30 July shock was accompanied by a rumble. Receding of the sea was noticed on the shore near Marmaro and was followed by numerous oscillations of the sea-level with a period of 10 $15 \mathrm{~min}$ and approximately $50-70 \mathrm{~cm}$ high which lasted for about $2 \mathrm{~h}$ (Galanopoulos, 1954). This refers to seiche waves in the Bay of Marmaro triggered by the tsunami. The natural period of seiches in this open-narrow bay $(\sim 2 \mathrm{~km}$ in length and $\sim 10 \mathrm{~m}$ deep; Heikell, 2001) can be calculated as around $12 \mathrm{~min}$

\section{Conclusions}

The Chios-Cesme (3 April 1881) and the Chios-Karaburun (23 July 1949) earthquakes are the most destructive events which affected the Chios-Cesme Strait (Aegean Sea) and its environment. Their epicenters were in the Southeast and Northeast parts of the island of Chios, respectively. Isoseismal maps prepared for these events indicate that the regions experienced a shaking intensity of MSK IX for both earthquakes which may have been produced by WNW-ESE trending faults to the South and North of the region (Fig. 2). Due to its topographical characteristics and the landslide events that occurred during the 1881 and 1949 earthquakes, the Chios-Karaburun region is prone to floods and landslides. Since historical structures and castles in the region are mainly located on the top of the hills and the slopes of the mountains, associated landslides may cause serious damage to sites of historical heritage. Lack of information on the occurrence of landslide events for uninhabited areas can be a serious drawback. Image drape-LANDSAT (7/5/36) of the region gives some clues on landslides that have occurred 
mostly at the NE parts of the Karaburun Peninsula, Chios and possibly in the island of Oinoussa (Fig. 6). The landslides experienced in Karaburun Peninsula took place on a thick Mesozoic platform which is made up of sheared tectonic slices due to the active extensional regime in the region. The terrestrial Neogene deposits on this platform, mainly composed of sandstone, marn, clay, limestone and silisium nodules, are prone to be easily affected by landsliding as well. In the meantime, NE Chios is a parautochthonous area that comprises some fragments detached from the autochthonous unit beneath the thrust plane of an allochthonous unit. On the other hand, the landslide proposed to be occurred in the Oinoussa islands is based on speculations arising from the study of satellite data, since there is no historical documentation for the landslides in these islands which are made up of an autochthonous unit built up of an epimetamorphic flysch sequence.

The Chios-Cesme and Chios-Karaburun earthquakes and their aftershocks produced some sea waves. They were not as dangerous as the ones in oceans but caused some destruction making further investigation of the tsunamis in the region necessary. Estimating possible tsunami sources and high risk zones are always useful in designing future developments. Besides examining the archival documentation, it will be also helpful to use some simulation techniques to get an understanding of the generation, propagation and coastal amplification of tsunamis in the region.

For our cases, tsunamis observed during 1881 and 1949 events can not be directly associated with the coastal landslides along the steep shores of the Chios Island and the Karaburun Peninsula. But it is believed that the earthquakes occurred on the CCF and CKF faults suggested in the present paper and some accompanying underwater failures are the main reasons of these tsunamis. Seafloor slope, slope direction, and roughness as defined by the curvature of contours, can aid the identification of potential slides more likely to produce tsunamis. In order to obtain a more accurate estimation of the expected areas for future tsunami activity, further investigation and additional geophysical studies are suggested. Abnormal depth changes reported in the postearthquake documents can be evaluated after some multibeam bathymetry, side scan sonar and high resolution marine seismic reflection studies.

Acknowledgements. Funding was allocated by the research fund of the Istanbul University; under project No. UDP-423/22022005. The authors thank C. Yaltirak for discussion of subaqueous marine faults from his seismic data sets. The authors thank S. Tinti and two anonymous referees who provided thoughtful comments on an earlier version of the paper.

Edited by: S. Tinti

Reviewed by: two referees

\section{References}

Turkish Republic Prime Ministry, General Directorate of the State (Ottoman) Archives:

BOA, Y.PRK.PT.1/76

BOA, YEE 78/143

Consulted newspapers collections:

Aksam, 24 July 1949

Aksam, 25 July 1949

Ceride-i Havadis, 28/29 October 1856

Cumhuriyet, 24 July 1949

Hürriyet, 25 July 1949

Impartial, 5 April 1881

Impartial, 7 April 1881

Journal de Constantinople, 19 October 1856

L'Agence Havas, 9 April 1881

L'Agence Havas, 13 April 1881

L'Agence Havas, 14 April 1881

La Turquie, 14 April 1881

Son Posta, 25 July 1949

Tercüman-i Hakikat, 10 April 1881

Vakit, 10 April 1881

Vakit 15 April 1881

Vatan, 25 July 1949

Ambraseys, N. N.: Engineering Seismology, Earthquake Engineering and Structural Dynamics, 17, 1-105, 1988.

Ambraseys, N. N. and Finkel, C.: The Seismicity of Turkey and Adjacent Areas 1500-1800, Eren Publishers, Istanbul, 240p, 1995.

Barka, A. and Reilinger, R.: Active tectonics of the Eastern Mediterranean region: deduced from GPS, neotectonic and seismicity data, Annali di Geofisica, 40, 587-609, 1997.

Benndorf, O.: Erdbeben von Scio im Jahre 1881, Deuche Rundschau, Berlin, 41, 371-378, 1884.

Besenecker, H., Durr, S., Herget, G., Kauffman, G., Ludtke, G., Roth, W., and Tietze, K. W.: Chios (2 sheets), Geological map of Greece at scale 1:50000, I.G.S.R. Athens, 1971.

Brinkmann, R., Fluegel, E., Jacobshagen, V., Lechner, H., Rendel, B., and Trick, P.: Trias, Jura und Unterkreide der Halbinsel Karaburun (West-Anatolien); Beiträge zur Geologie von Anatolien, No. 13, 1972.

Dewey, J. F. and Sengör, A. M. C.: Aegean and surrounding regions: complex multiplate and continnuum tectonics in a convergent zone, Bull. Geol. Soc. Amer., 90, 84-92, 1979.

Earthquake Hazard Regionalization Map of Turkey.: Türkiye Deprem Bölgeleri Haritasi, T.C. Bayindirlik ve Iskan Bakanligi, Afet Isleri Genel Müdürlügü, Deprem Arastirma Dairesi Baskanligi, Ankara, 1996.

Erdogan, B., Güngör, T. and Ozer, S.: Stratigraphy of Karaburun Peninsula, Bulletin of the Mineral Research and Exploration Institute of Turkey, 111, 1-20, 1990.

Erkman, H.K.: 23 July 1949 Karaburun (Izmir) Zelzelesi (Le tremlement de terre de Karaburun -Smyrne), Milli Egitim Bakanligi, Istanbul Kandilli Rasathanesi, Sismik Yayinlar:1, Sirketi Mürettibiye Basimevi, No. 73, Istanbul, 1949.

Eyidogan, H.: Rates of crustal deformation in western Turkey as deduced from major earthquakes, Tectonophysics, 148, 83-92, 1988.

Eyidogan, H., Güclü, U., Utku, Z., and Degirmenci, E.: Türkiye Büyük Depremleri Makro-sismik Rehberi (1900-1988), ITU Maden Fakultesi Jeofizik Müh. Böl, Istanbul, 1991.

Galanopoulos, A.: Die Seismizität der Insel Chios, Gerl, Geitr. Z. Geophys., Leipzig, 63, 253-264, 1954. 
Heikell, R.: Greek Waters Pilot, Imray, Laurie and Wilson Ltd., England, 8th Edition, 506 p., 2001.

Hellenic Ministry of Culture web site http://www.culture.gr/, 2005.

Henriet, M.J.: Mémoire sur les tremblements de terre de l'ile de Chio, in: Anneles de Chimie et de Physique, Cinuième SérieTome XXVIII, edited by: Masson, G., Imprimerie de GauthierVillars, Paris, France, 1883.

Isintek, I.: Foraminiferal and algal biostratigraphy and petrology of the Triassic to Early Cretaceous carbonate assemblages in the Karaburun peninsula, western Turkey: $\mathrm{PhD}$ thesis, Dokuz Eylül Universitesi, Jeoloji Mühendisligi Bölümü, IzmirBornova, Turkey, 263 p., 2002.

Kastaniya, A.: $\Lambda$ eyk $\omega$ ma $\mathrm{t} \omega \mathrm{n}$ epei $\mathrm{i} \omega \mathrm{n}$ th $\sigma$ Xioy (Album of the ruins of Chios Island), $\sigma$ yne $\pi$ eia $\mathrm{T} \omega \mathrm{n} \Sigma$ ei $\sigma \mathrm{m} \omega \mathrm{n}$ th $\sigma 22 / 3$ A $\pi$ pi $\lambda$ ioy 1881 (Results of the 22/3 April 1881 Earthquake), $\Phi \omega$ to $\gamma$ pa $\phi$ ie $\sigma$ A $\delta$ e $\lambda \phi \omega$ n Ka $\sigma$ tania (Photographs vy Adelfon Kastaniya), A $\theta$ hnai (Athens), $\Gamma$ enna $\delta$ eio $\sigma$ Bib $\lambda$ io $\theta$ hkn (Gennadeios Library), 60 p., 1983.

Koravos, G. Ch., Main, I. G., Tsapanos, T. M., and Musson, R. M. W.: Maximum earthquake magnitudes in the Aegean area constrained by tectonic moment release rates, Geophys. J. Int., 152, 94-112, 2003.

Kozur, H.: The age of the siliciclastic series (Karareis Formation) of the western Karaburun peninsula, western Turkey: Paleontologia Polonica, 58, 171-189, 1998.

Mascle, J. and Martin, L.: Shallow structure and rcent eolution of the Aegean Sea: a synthesis based on continuous reflection profiles, Mar. Geol., 94, 271-299, 1990.

McKenzie, D.: Active tectonics of Alpine-Himalayan belt: the Aegean Sea and surrounding regions, (Tectonics of Aegean region), Geophys. J. R. Astr. Soc., 55, 217-254, 1978.

Pinar, N.: Etude géologique et seismologique du tremblement de terre de Karaburun (Izmir) du 23 juillet 1949, Revue de la Faculté des Sciences de l'université d'istanbul, Istanbul, 15, 363-375, 1950.

Papanikolaou, D. J. and Sideris, Ch.: Introduction to the Geology of Chios Island, 5th Meeting of IGCP Project 276, Chios-Lesvos, 25-31 May 1992, Athens, Greece, 1-19, 1992.

Papazachos, B. and Papazachou, C.: The Earthquakes of Greece, Ziti Editions, Thessaloniki, 304 p., 1997.

Papazachos, C. B., Karakaisis, G. F., Scordilis, E. M., and Papazachos, B. C.: Probabilities of activation of seismic faults in critical regions of the Aegean area, Geophys. J. Int., 159, 679-687, 2004.

Robertson, A. H. F. and Pickett, E. A.: Paleozoic-Early Tertiary Tethyan evolution of Mélanges, rift and passive margin units in the Karaburun Peninsula (western Turkey) and Chios Island (Greece), in: Tectonics and magmatism in Turkey and surrounding area, edited by: Bozkurt, E., Winchester, J. A., and Piper, J. D. A., Geological Society of London, Special Publication, 43$82,2000$.
Rosselet, F. and Stampfli, G.: The Karaburun Units, a remnant of the Paleotethys fore-arc basin: Abstract in 1st International Symposium of the Faculty of Mines (ITU) on Earth Sciences and Engineering, Istanbul, Turkey, 2002.

Sannav, S. C.: 1881 Sakiz depremi ve adanin yeniden imari, Istanbul Universitesi, Edebiyat Fakültesi Tarih Dergisi, No. 4470, 125-138, 2004.

Shebalin, N. V.: Atlas of isoseismals, Part III, UNDP/UNESCO Survey of the Seismicity of the Balkan Region, Skopje, 1974.

Soleviev, S. L., Solovieva, O. N., Go, C. N., Kim, K. S., and Shchetnikov, N. A.: Tsunamis in the Mediterranean Sea, 2000 B.C.2000 A.D., Advances in Natural and Technological Hazards Reseach, Kluwer Academic Publishers, 237 p., 2000.

Soysal, H., Sipahioglu, S., Kolcak, D., and Altinok, Y.: Türkiye ve Cevresinin Tarihsel Deprem Katalogu (MO. 2100-MS. 1900), TUBITAK, Project No: TBAG 341, Istanbul, 87 p., 1981.

Tadepalli, S. and Synolakis, CE.: The runup of N-waves. Proceedings of the Royal Society, London, Series A, 445, 99-112, 1994.

Vogt, J.; Seismicité historique du domaine Ottoman: types de sources occidentals et exemples de temoignages, in: Natural Disasters in the Ottoman Empire, edited by: Zachariadou, E., Crete University Press, Greece, 15-55, 1999.

Walder, J. S., Watts, P., Sorensen, O. E., and Janssen, K.: Tsunamis generated by subaerial mass flow, J. Geophys. Res., B5, doi:10.1029/2001JB000707, 2003.

Watts, P.: Wavemaker curves for tsunamis generated by underwater landslides. Journal of Waterway, Port, Coastal, and Ocean Engineering, ASCE, 124(3), 127-137, 1998.

Wessel, P., Smith, W.H.F.: New, improved version of generic mapping tools released. EOS Trans. AGU, 79, 47, 579, 1998.

Westaway, R.: Evidence for dynamic coupling of surface processes with isostatic compensation in the lower crust during active extension of western Turkey, J. Geophys. Res., 99, 20 203-20 223 , 1994.

Wormsworth, J.: Interdisciplinary Rescue Response - Izmir, Turkey, Investing in Lives: Improving Rescue in Turkey, ICET, Risk Crisis and Disaster Management, http://www.icet.nl/ INHOUD/Engels/Consultancy/CSIzmir.html, 2003.

Yilmaz, Y.: Geology of Western Anatolia, in: Active Tectonics of NW Anatolia - The Marmara Poly-project, edited by: Schindler, C. and Pfister, M., VDF, ETH Zurich, 1997. 